$\begin{array}{llll}\text { Submitted } & : \mathbf{2 9 . 0 9 . 2 0 2 0} & \\ \text { Accepted } & : 06.12 .2020 & & \\ \text { Year } & : \text { December } 2020 & \text { Volume: } 1 \quad \text { Issue: } 2 \\ \text { DOI } & : 10.47333 / \text { modernizm.2020265785 }\end{array}$

\title{
FROM SLOTHFUL WANDERERS TO CRAWLING BODIES: DANTE'S BELACQUA AS BECKETT'S MODERN EVERYMAN ${ }^{1}$
}

Selvi Danaci ${ }^{2}$

\begin{abstract}
Dante Alighieri (1265-1321) was a life-long obsession for Samuel Beckett (1906-1989), and the Divine Comedy (1320) had a great impact on his literary trajectory. Concerned with "Purgatory" in particular, Beckett was fascinated with Dante's Belacqua, a character Dante encounters in Ante-purgatory where the souls wait for a lifetime in order to begin their journey of purgation. Belacqua is portrayed by Dante as a slothful figure who is not much interested in purging his soul and seems quite content with his lethargic state. While for Dante, Belacqua is a pitiful soul, an epitome of sloth, and a negative example for humankind; for Beckett, he is the ultimate representative of the modern man who has lost his purpose in life and his will to make sense of the world he occupies. In Beckett's novels, then, Dante's Belacqua is transformed from an exemplary character serving for a moral message into an 'everyman' figure reflecting the existential predicament of the twentiethcentury individual. Dante's Belacqua, in this sense, constitutes the gist of Beckett's outsider protagonists who are depicted as aimless and indifferent wanderers. Therefore, these characters are portrayed as merely different versions of Belacqua. In this light, this article purposes to discuss how Beckett adapts Dante's Belacqua to the twentieth-century context and revives him as the epitome of the modern everyman who suffers from an existential plight, and how Beckett's oeuvre is, indeed, shaped by this very character.
\end{abstract}

Keywords: Samuel Beckett, Dante, The Divine Comedy, Belacqua, Modernist Novel

\section{MISSKIN AVARELERDEN SÜRÜNEN BEDENLERE: BECKETT'IN MODERN INSANI OLARAK DANTE'NIN BELACQUA KARAKTERI}

\section{Öz}

Dante Alighieri (1265-1321) Samuel Beckett (1906-1989) için hayatı boyunca bir saplantı olmuştur ve the Divine Comedy'nin (1320) edebi çizgisi üzerinde büyük bir etkisi vardır. Özellikle "Purgatory" bölümü ile ilgilenen Beckett, Dante'nin ruhların arınma yolculuklarına başlamak için bir yaşam süresi kadar bekledikleri Ante-purgatory'de karşılaştığı Belacqua karakterinden etkilenmiştir. Belacqua Dante tarafindan ruhunu arındırmakla pek ilgilenmeyen ve uyuşuk halinden oldukça memnun olan tembel bir ruh olarak resmedilir. Dante için Belacqua acınası bir ruh, tembelliğin bir timsali ve insanoğlu için olumsuz bir örnek iken, Beckett için hayattaki amacını ve bulunduğu dünyayı anlamlandırma isteğini yitirmiş olan modern insanın nihai temsilidir. Böylece Beckett'in romanlarında Dante'nin Belacqua'sı ahlaki bir mesaja hizmet eden örnek bir karakterden yirminci yüzyıl bireyinin içinde bulunduğu varoluşsal çıkmazı yansıtan bir insan modeline dönüşür. Bu noktada, Dante'nin Belacqua'sı Beckett'in amaçsız ve kayıtsız avareler olarak betimlenen aykırı karakterlerinin özünü oluşturur. Bu yüzden, bu karakterler Belacqua'nın yalnızca farklı yorumları olarak tasvir edilir. Bu bakımdan, bu makale Beckett'in Dante'nin Belacqua'sını nasıl yirminci yüzyıl bağlamına uyarladığını ve onu nasıl varoluşsal çıkmazdan muzdarip olan modern insanın timsali olarak yeniden yarattığını ve Beckett'in eserlerinin aslen bu karakter tarafından nasıl şekillendiğini ele almayı amaçlamaktadır.

Anahtar Kelimeler: Samuel Beckett, Dante, the Divine Comedy, Belacqua, Modernist Roman

\footnotetext{
${ }^{1}$ The main argument of this article originates from my M.A. thesis, titled "Redefinition of Purgation in Samuel Beckett's Dream of Fair to Middling Women, Mercier and Camier, How It Is." However, except from some shared secondary sources and quotations, the submitted article and the above-mentioned thesis are two separate works that present arguments on different topics and focus on different contexts. While the M.A. thesis discusses Beckett's subversive interpretation of Dante's concept of purgation in three of his novels, the submitted article argues that Dante's idle character in the Divine Comedy, Belacqua, is the source of inspiration for Beckett's modern everyman, and Beckett adopts Dante's Belacqua throughout his literary career to portray the predicament of the modern individual. In this respect, the submitted article and the M.A. thesis have two separate thesis statements and contents
}

$2 \mathrm{PhD}$ Candidate, English Language and Literature, Hacettepe University, selvidanaci@gmail.com, https://orcid.org/0000-0002-0889-5713 


\section{Introduction}

Samuel Beckett's fictional world was highly influenced and, to a certain degree, shaped by Dante Alighieri's the Divine Comedy. Having read it when he was young with the help of his Italian tutor Bianca Esposito and keeping his old schoolboy copy of the text even at his deathbed, it is quite evident that Beckett was obsessed with Comedy ${ }^{3}$ throughout his life (Caselli 1; Wallace 299). A medieval work on the spiritual journey of mankind from damnation to salvation, Dante's Comedy was considered by Beckett as a source of artistic and philosophical inspiration rather than a religious or a moral guidance. Fascinated with the second realm, Purgatory, in particular, Beckett was mostly concerned with the representation of the torments and suffering that the souls endure for the sake of spiritual purgation and eventual salvation. Among numerous residents of Purgatory, the character named Belacqua in Ante-purgatory ${ }^{4}$ is the key figure in understanding Beckett's obsession with Dante's highly religious text. Portrayed by Dante as a soul crouched by a rock, his head between his knees, Belacqua is the exact representative of sloth. Due to having repented only at the end of his life, Belacqua is doomed to wait for a lifetime in Ante-purgatory in order to begin his purgative journey through Purgatory. With his physical posture, lethargic disposition, and spiritual predicament, Belacqua is the very model upon whom Beckett creates his characters. Much like Dante's medieval soul who is trapped in a limbo-like realm where waiting appears to be his punishment, Beckett's derelicts, who can be taken as the epitomes of the modern individual, are as well mired in a twentiethcentury version of Ante-purgatory where they suffer from existential crisis, mental confusion, individual isolation, aimlessness, and inbetweenness. This affinity between Dante's Belacqua and Beckett's outsiders can be observed in almost all his works, from his novels to his plays. In Beckett's fictional world, Dante's Belacqua is not only a major influence, but he turns out to be every single one of Beckett's drifters, shifting shape and changing according to Beckett's increasing pessimism towards the world and individual existence. While his physical posture and general disposition becomes a trademark for Beckettian man, Belacqua's indolent and numb condition in Ante-purgatory appears as a paradise-like state for his modern descendants. In this sense, Beckett's novels, which will be the focus of this article examining Belacqua's presence in his works, provide a vast range of characters through whom Beckett's portrayal of the modern individual can be analysed.

\section{DANTE'S PURGATORY AND BELACQUA}

Composed of three parts, namely "Inferno," "Purgatory," and "Paradise," Dante's Comedy is fundamentally a text on the meaning and purpose of man's existence on earth, as well as a religious and moral commentary on the divine order of the universe and a spiritual guidance on mankind's salvation. As Brandeis also puts it, Comedy "is literally a voyage through Hell, Purgatory and Heaven and, allegorically, a search for understanding of the order and nature of the universe, projecting a moral geography of the soul and a Christian examination of the soul's wanderings from and return to God" (12). Indeed, the work follows Dante the narrator, who is lost in a dark forest in the "[m]idway the journey of this life" (Comedy, "Inferno," I.1-2), finding his way from damnation in Inferno to salvation in Paradise. While Dante portrays in "Inferno" the sufferings of the souls who are eternally damned and denied divine wisdom and eternal peace, in "Paradise," he lays bare the divine order of the universe and the true reflection of God's grace. In the midst of this spiritual quest, there is Purgatory, which is at the centre of Beckett's interest in Comedy. Depicted by Dante as a mountain, Purgatory is the realm where souls endure various torments in order to be purged from seven deadly sins and allowed in Paradise. In this respect, it propounds a certain type of religious principle defined by a punishment and reward correlation. As T.S. Eliot articulates, "[i]n purgatory the torment of flame is deliberately and consciously accepted by the penitent... The souls in purgatory suffer because they wish to suffer, for purgation" ("Dante," 716). In the same vein, the souls that Dante comes across in Purgatory abide their torments quite voluntarily since they have complete faith in the fact that they will be saved once they are purified from the sins they committed on earth.

\footnotetext{
${ }^{3}$ The Divine Comedy will be abbreviated as Comedy hereafter.

${ }^{4}$ A sub-territory of Purgatory.
} 
What relates Purgatory to Beckett's understanding of life is more to do with the constant state of suffering than the promise of redemption. For him, life itself is purgatorial minus the eternal peace in Paradise. According to Fletcher, for Beckett, "[s]alvation is a fairy-tale, ... [and] [m]an's only fate is to die; all attempts to soften this harsh fact are lies ... Man's body is split from his mind, and the two carry on an unremitting war: the body crumbles, but the mind is not much more favoured, since true knowledge is impossible and epistemological uncertainty is a constant of our condition" (Samuel Beckett's Art, 12-13). In line with this argument, it can be claimed that Beckett's pessimistic attitude towards individual existence is highly explicit in his fictional universe where the individual attempt to be saved is deemed futile and the suffering is perpetual. Regarding Beckett's interpretation of the function of Dante's Purgatory, Kalt states that "Dante's anticipation of Salvation and Paradise is replaced by Beckett's horror at the individual's arbitrary state of helplessness in a perpetual purgatory, with no hope of Heaven" (15). Correspondingly, with Dante's optimism regarding the divine order and the purpose of mankind disturbed by the terror that Beckett's fictional universe and his people are subjected to, his portrayal of life and individual struggle in his fiction stands as a twisted version of Dante's vision of Purgatory.

The foremost example of this subversive interpretation of Purgatory is found at the foot of Mount Purgatory. In Comedy, Purgatory is divided into three spheres: Ante-purgatory, where the late repentant souls are forced to wait for a lifetime in order to begin their purgative torments; Purgatoryproper, where the souls undergo a series of torments on seven terraces of the mountain in order to be purged from seven deadly sins; and the Garden of Eden, or the Earthly Paradise, which the purified souls pass through to be allowed in Paradise. When Dante, guided by Virgil, arrives at the foothills of the mountain, that is Ante-purgatory, he comes across with a soul among many others. Belacqua, an old friend of his, is sitting by a rock in a crouched position, his head between his knees. As mentioned earlier, one of the late repentants, Belacqua as well has to wait for a lifetime in order to climb the mountain. However, as Dante also discerns, Belacqua, unlike other characters in Comedy, is quite indifferent towards his surrounding and the whole concept of purgation. Depicted by Dante as the one "who more indifferent shows / Himself than if Sloth were his own sister" (Comedy, "Purgatorio," IV.110-111), Belacqua is indeed the only character in Comedy who is not interested in telling his story or striving to be saved. Upon Dante's asking the reason for his indifference, he responds as follows:

What boots it, brother, to resort

Up there? God's angel, sitting at the gate

My passage to the penances would thwart. (Comedy, "Purgatorio," IV.127-130)

He not only remains indifferent to the entire process of purgation, but Belacqua also justifies his passivity by simply saying that it does not matter whether he bothers to climb the mountain or not, since he is not allowed to step out of his territory anyway. As O'Neill argues:

This is a strange statement to come from a soul destined for Paradise. [Belacqua] shows none of the great desire seen in the other souls of Ante-Purgatory; he seems defeated or even disinterested. Perhaps the 'martiri' (torments) are not so appealing to him: after all, having been so lazy during his lifetime, what he undergoes in AntePurgatory is something of a paradise for Belacqua. What lies ahead -his many years of purgation - must seem like a step in the wrong direction. (35)

Of course, it should also be noted here that it is only natural for Belacqua to assume this sort of an indifference knowing that he will eventually be saved once his waiting for a lifetime is due. Accordingly, there is indeed no point of trying to climb the mountain or making an effort for salvation. The realm where Belacqua inhabits, in fact, tolerates, or to put it more correctly, necessitates this state of indolence. However, as opposed to other late-repentant souls in Ante-purgatory, who pay attention to Dante's presence as a living man with a shadow and seem eager to tell their stories (Comedy, "Purgatorio," III. 4-9), Belacqua resumes his "wonted part" (Comedy, "Purgatorio," IV.126), that is, he easily adapts to the necessary state of inertia that Ante-purgatory conditions since, according to Dante, he was no different when he was alive. Along with the sense of confidence that comes with the fact that he will be saved, the constant state of waiting and doing nothing, which is supposed to be a punishment, or even a torment for the souls in Ante-purgatory, is something that Belacqua seems to be enjoying. As Cohn asserts, "[u]nlike the damned of the Inferno, ... whose sin becomes the fulcrum of 
their punishment, Belacqua's fault feeds his preference. Indolent in life, he is indolent after death, motionless in the shade of a rock" (Back to Beckett, 16). At this point, Belacqua's sin, his punishment and his condition in Ante-purgatory must be distinguished from the souls in Inferno and Purgatoryproper who are associated with similar sins of assuming an indifferent and slothful disposition in life. Unlike the souls referred to in "Inferno," who led a life devoid of purpose or responsibility, "without infamy and without praise" (Comedy, "Inferno," III.36) and now are forced to bear their eternal punishment of chasing a banner naked and tortured by wasps and hornets, or the souls in the fourth terrace of Purgatory-proper, whose sin of sloth results from insufficient love and caring (Bergin 48), and whose punishment is the opposite of their general attitude in life, which is to move incessantly with desire and with "zeal for good" (Comedy, "Purgatorio," XVIII.105); Belacqua's punishment of waiting is due to his negligence of repentance. What is distinctive about his punishment for his sin of being indifferent and slothful is the fact that his punishment is not quite different from how he spent his life. Therefore, as Dante also observes with a faint smile on his face, it can be argued that the apparent predicament of passivity in the realm actually suits Belacqua's disposition. Indeed, indifferent all through his life, Belacqua appears to find this lethargic condition quite pleasing rather than punitive given the fact that the first reaction he gives to Dante is to offer him the same condition of inactivity when he suggests that Dante take a rest. In this respect, as Sperandio argues, "Belacqua is the embodiment of the exact opposite perspective that has made Dante arrive at the same point of the journey: Dante's movement and zeal are, programmatically and purposefully, in full and open contrast with Belacqua's sloth and immobility" (178). In line with this argument, it is possible to claim that Belacqua's entire being stands as a negation to Dante's upward motion in both physical and spiritual sense. The lifelong waiting with nothing to do is presented not so much as a torment for Belacqua, but rather a perpetuation of his former condition. It is this characteristic of him that relates Belacqua to Beckett's outsiders, and the state he is in is a source of inspiration for Beckett to form his characters. While Dante depicts Belacqua as a negative example of human soul consumed by lethargy and negligence, and presents his condition as a necessary step before the process of purgation and the journey towards salvation begin, Beckett subverts the notion of a promised Paradise by placing his characters, who share similar personal characteristics with Dante's Belacqua, in a darker purgatorial universe where their chief objective is to achieve the spiritual numbness that Dante's Belacqua seems to enjoy in Ante-purgatory. In Beckett's fictional world, Belacqua's sin of negligence, as well as its punishment, is transformed into a bliss for his modern everyman.

\section{BECKETT'S BELACQUAS}

The characters that constitute the long line of Beckettian everyman, from Murphy (Murphy, 1938) to Molloy (Molloy, 1951), Malone (Malone Dies, 1951), Unnamable (the Unnamable, 1953), Pim (How It Is, 1961) and so forth, all share certain defining characteristics with Dante's Belacqua. Sperandio states that "Beckett's characters are all somehow connected to a primigenial Belacqua, the epitome of helpless, comic, tragic, paradoxical immobility" (165). As the representatives of modern individual, these "helpless," "comic," and "tragic" outsiders are either in a constant state of waiting as if in Ante-purgatory, or of suffering as if in Purgatory-proper. Much like their medieval predecessor, they seem to be trapped in a world whose boundaries they are not allowed to transgress. As Coe also suggests, "Purgatory is the residence of every different manifestation of Beckett's moi: it is the home of Man" (5). This purgatorial world they occupy is sometimes a European city, a countryside, a barren land, or bogs where Beckettian man wanders aimlessly or with a vague and unnamed purpose, and sometimes it is merely a pile of mud through which he crawls or simply waits. However, these modern Belacquas lack the indolent peace that Dante's idle soul enjoys. Since Beckett's universe does not allow them such sense of comfort and numbness, they tend to assume an anxious state of mind and a deteriorating physical plight. As Strauss propounds:

[i]n Dante's world Purgatory is the necessary ascent to perfection and innocence, in which the pilgrim is purged of vices and learns to understand the corresponding virtues. Antepurgatory is a preparation, a trial by waiting before the ascent begins. In Beckett's own words, the difference between Antepurgatory and Purgatory is the difference between real and ideal vegetation; and Beckett saw in the Joycean purgatory the conditions of his own world -no ascent and no ideal vegetation. The heroes of Beckett's universe really vegetate, and since this fate is unendurable, they 
try to vegetate ideally, i.e., they persuade themselves that there $i s$ an ascent and wait for some sort of angel to beckon them on, like Dante's pilgrims. But the angel, the epiphany, never comes, and they finally return to real vegetation. Like the vegetable, they wilt and disintegrate. (260)

Accordingly, unlike Dante's vision, which guarantees salvation and peace at the end of the punishment, in Beckett's world, there is only pain and perennial search for a paradise which is deemed unattainable. In this sense, Beckett's everyman can be taken as Dante's Belacqua who is taken from his indolent rest in Ante-purgatory and thrown into the twentieth-century chaos in which he is troubled and tormented by the world and is trying to get back home to Ante-purgatory, to his "ideal vegetation." Beckett's lethargic Belacquas wander around to find that Belacquan space where body no longer rules the mind and the mind is no longer disturbed by the burden of thinking. In a way, they are the different versions of Dante's Belacqua who long to return to and resume their rightful place. They strive to leave the outer reality behind them and find a loophole where they can be freed from physical existence. Therefore, throughout their fictional endeavours, Beckett's people attempt to reach that Belacqua bliss in Ante-purgatory where they believe they will be in utmost peace having relieved of their physical burden; yet, every attempt is doomed to be inconsequential and results in failure.

As Beckett's attitude towards life becomes more pessimistic and gloomier, his portrayal of Belacqua grows more cynical. While Belacquas in his earlier novels are depicted as more or less capable of adapting to the outer reality and portrayed as the citizens of the society in Federman's words despite their apparent lack of interest in being a part of this society (33-34); in the works which were written after the Second World War, the Beckettian everyman appears as a vagabond who still occupies a space in the physical world, but is not actually a part of this particular world. These characters are rather expelled from the society and portrayed as excluded derelicts in decaying mental condition with physical deformities and tramp-like clothes. In Beckett's later fictional works, from fifties to sixties and onwards, his Belacquas finally get rid of their physical burdens. They are either mouths without bodies, voices without bodies, or deformed bodies that have lost their ability to function properly. However, what these decaying beings eventually find is not a paradise-like loophole, but on the contrary, a Beckettian version of hell where they are far from being at peace with the nullity of their bodies or the emptiness of their minds. Thus, with a paradise-like Ante-purgatory always being forsaken, the plight of the modern Belacquas is gradually exacerbated through Beckett's oeuvre.

\section{Slothful Wanderers: Belacqua and Murphy}

Beckett's first novel, Dream of Fair to Middling Women (1932), can be considered as the first appearance of Belacqua as a twentieth-century interpretation of Dante's idle soul. The story of a man named Belacqua and his love affairs with various women in different European cities, Dream ${ }^{5}$ revives Dante's Belacqua as a young Irish man who oscillates between the outer reality and the indolence of his mind. Fletcher adverts that

[t]o suit his own purposes [Beckett] never hesitates to twist Dante's meaning: Belacqua is conceived to be in an incomparable state of bliss, quite contrary to Dante's real conception, and Limbo, the bleak realm which the poet does not portray as very attractive ... is regarded by Beckett's hero as an agreeably peaceful place, where one exists not burning with desire but 'purged of desire'. (Samuel Beckett's Art, 113)

In the same vein, the novel follows Belacqua travelling through Vienna, Paris and Dublin, having complicated relationships with young women, most of whom force him into physical intimacy despite his deliberate avoidance. In fact, throughout the novel, Belacqua strives to escape from all sorts of social responsibilities that tie him to the outer reality. He prefers his relationships with these women to be in his fantasies, which he thinks makes them ideal. He appears to be a promising academic, yet he also avoids taking a step in that direction. Generally confused about his inability to keep pace with the world surrounding him, Belacqua aspires to exist in the indolence of his mind. Occasionally in the

\footnotetext{
${ }^{5}$ Dream of Fair to Middling Women will be abbreviated as Dream hereafter.
} 
novel, he achieves that temporary repose in his mind, which he wishes to enjoy permanently, as the narrative follows: "[h]e was bogged in indolence, without identity, impervious alike to its pull nor goad. His third being was without axis or contour, its centre everywhere and periphery nowhere, an unsurveyed marsh of sloth" (Dream, 121). In these lethargic moments, which resemble brief breaks from the reality, Belacqua's mind is free from the burden of his body. As Fletcher also points out, " $[t]$ his urge to retreat into the wider freedom of the mind springs from an underlying dualistic conviction, entailing the consequence that the mental part of one's being desires continually to escape from the contingencies of the physical part" (The Novels, 36). The source of Belacqua's predicament, then, is the conflict between the inner and the external world, in other words, the never-ending battle between the body and the mind. The side Belacqua takes is evidently the mind, which offers him a shelter from the chaos of the outer world. Cronin calls this place of retreat Limbo as he propounds, "Limbo is the place in which there is neither salvation nor damnation, where there is no becoming, but only an eternal state of dim being. Limbese was Beckett's word for the state of self-centred, mildly gloomy meditativeness and detachment in which he liked to live, with the outer world shut away, its noises meaningless, its struggles pointless" (161-162). This state of complete indolence and indifference is the bliss that Dante's Belacqua so willingly embraces during his punishment in Antepurgatory, and this state that shuts down the physical world and lets the mind rest in meditative silence is what Belacqua pursues.

In this sense, Belacqua is not the only Beckettian daydreamer that aspires and occasionally enjoys this state of indolence. Murphy, in the namesake novel (1938), is another version of Dante's Belacqua, trapped in the twentieth-century reality, seeking a way out to abandon his corporeal existence. Dylan Thomas considers the novel as, "the study of a complex and oddly tragic character who cannot reconcile the unreality of the seen world with the reality of the unseen, and who, through scorn and neglect of 'normal' society, drifts into the society of the certified abnormal in his search for 'a little world."' (50). Throughout the whole novel, then, one witnesses the journey of a young man who is trapped between the material world and his inner self, prefers "to escape the limitations of the body in order to enjoy freedom in the mind", and eventually "realizes how impossible it is to escape the physical world" (Federman 64). Murphy's rocking chair, in which he rocks himself to a state of unconsciousness, is a gate to that temporary bliss in Ante-purgatory, which he calls the "Belacqua bliss," (Beckett, Murphy, 65) and it is found in a place he calls the third zone like Dream's Belacqua. In this temporary state of mind during his time in the rocking chair, "he was not free, but a mote in the dark of absolute freedom... Thus as his body set him free more and more in his mind, he took to spending less and less time in the light, spitting at the breakers of the world... and more and more and more in the dark, in the will-lessness, a mote in its absolute freedom" (Beckett, Murphy, 65-66). Commenting on these brief moments of Belacqua bliss, Webb states that

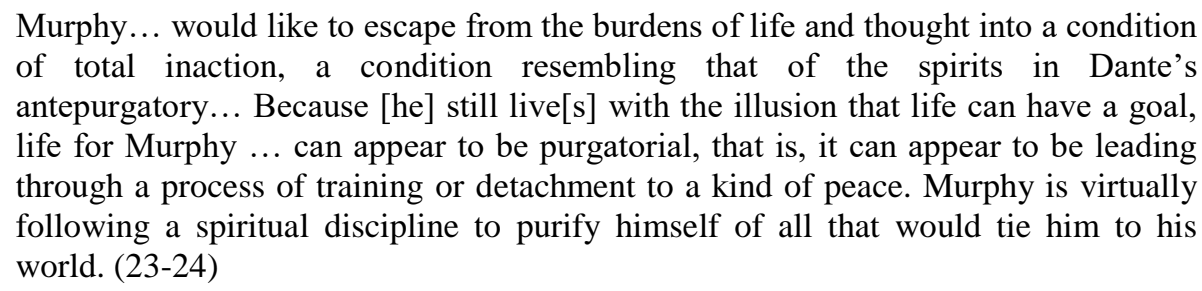

Except from these numb moments, Murphy is obliged to function as a part of the society. Like Belacqua of Dream, Murphy is a citizen of the world working as a caretaker in an asylum, having a girlfriend and being more or less a conventional protagonist in Beckett's universe. No matter how he tries to unite with his mind through the chair, the physical world always intervenes between them by controlling his body. Although he is able to feel free in his mind in these private moments, this feeling is only temporary. Relevant for Murphy's case as well, Federman comments on Belacqua's oscillation between his body and mind as follows:

His actions, obsessions, and idiosyncrasies prepare the personalities of the later eccentrics. Compared, however, with Beckett's French derelicts, most of whom spend their absurd existence vegetating in some nameless, moribund landscape, Belacqua is a normal and traditional hero. Primarily concerned with the physical self, he functions as a social man who has to cope with all the trivialities of life in 
society. ... However, being thus concerned by social, physical, and marital impositions, Belacqua assumes a lethargic, sardonic, and particularly a cowardly posture in all his actions. (33-34)

Much like Belacqua, then, Murphy cannot achieve the ultimate union with the mind due to the interruptions of the world outside, either in the form of a job or an alarm clock. What is also significant is that this distracting physical reality is often associated with Celia, the prostitute girlfriend of Murphy. Much like in the case of Belacqua, the needs of the body in the form of physical intimacy with women is what keeps Murphy attached to the outer reality, which he so eagerly attempts to escape. As Cohn adverts, "Murphy finds that women are the main obstacle to his retreat into the pure life of the mind... Murphy's mind and body are in conflict over Celia, who has streetwalked her way into the affections of the latter" (33). Both her physical presence and her demands on Murphy to get a job prevent him from achieving the ultimate isolation from his surroundings, which also leads to his death at the end of the novel. Federman interprets the ending asserting that "Murphy is destroyed in the end because he is unable to choose between mental nothingness (chaos and failure) and his own physical desires." (86). Correspondingly, both Belacqua and Murphy remain predominantly as "social" beings with interests in sex, alcohol, relationships, literature and art, and they cannot break their ties with the concerns of the physical world surrounding them. Though neither can achieve his rightful state like their medieval equivalent, both Belacqua and Murphy are granted a way out of their plight, in that, they die. As more realistically portrayed characters compared to Beckett's later outcasts, Belacqua and Murphy still remain socially accepted characters with slothful tendencies, and by dying, they are spared from the never-ending suffering of their descendants. While Belacqua dies during a surgery in Beckett's short story collection, More Pricks Than Kicks (1934), Murphy dies due to a gas leak at work. In this respect, their sudden deaths bring an end to their misery and the inbetweenness they suffer.

\section{Outcasts of the Transitional Period: Mercier and Camier}

With respect to the works written mostly in the late forties - the period when Beckett started writing in French - there is a certain change in the characters who appear to be cast out from the society rather than avoiding it willingly. What forces Belacqua and Murphy to abide by the physical world around them and more or less function as members of the society does not apply to the early French tramps, who, despite occasionally appearing in public, eventually find themselves exiled. Not only do they seek a new form of existence outside the limits of their bodies like the earlier heroes, but in their case, also the outer reality does not tolerate them. Regarding this change, Federman argues that

such figures as Belacqua ..., Murphy, and Watt, despite their eccentricities, are reasonably motivated by and humanly concerned with daily life... While [they] strive to reach some refuge away from the fiasco of society, and temporarily attain such asylum, the heroes of the early French works, after having enjoyed a brief stay in what appears to have been a bourgeois home or a mental institution, are suddenly expelled. Yet they do not return to life in society among their fellowmen, but rather face a much more distressing existence outside reality, within the solitude of their incoherent minds, within the unpredictable world of fiction. (18-21)

Although these characters have a vague connection with the physical world, such as remembering their old professions or families and having earthly belongings, it is often indicated that they are isolated from the society to such an extent that they are trapped in their own delusional world. An example to this type of character is the pseudo-couple Mercier and Camier from the namesake novel, Mercier and Camier (1946). The predecessors of Vladimir and Estragon from Waiting for Godot (1949), Mercier and Camier are the first French heroes of Beckett's fictional universe. The whole novel follows them as they try to leave an unnamed city, wander through the countryside, and reach a goal which is never identified throughout their story. For Federman, this pointless journey has both a physical layer, in which Mercier and Camier are surrounded by streets, canals, bogs, pubs, brothels, and the countryside, and a metaphorical layer, which makes the journey a quest for a non-physical existence, an escape from the physical and social reality (142-143). This route filled with idle roaming, pub crawl, brothel visits, and waiting is their purgatorial journey, during which they are constantly scorned and expelled by pub owners, prostitutes, and other members of the society into the bogs of the countryside. Like 
Belacqua and Murphy, Mercier and Camier frequently wander the streets of a city and mostly the bogs and countryside, searching for the opposite of physical existence, which is not death. It is not named what they are searching for, but it is hinted throughout the novel that they are trying to get rid of their earthly possessions, responsibilities, and corporeal needs, such as food, sex and so forth, and achieve something else. Their eagerness to leave the physical world behind is displayed in the following extract:

\begin{abstract}
We didn't leave anything in the pockets by any chance? said Mercier.
Punched tickets of all sorts, said Camier, spent matches, scraps of newspaper bearing in their margins the obliterated traces of irrevocable rendez-vous, the classic last tenth of pointless pencil, crumples of soiled bumf, a few porous condoms, dust. Life in short.
\end{abstract}

Nothing we'll be needing? said Mercier.

Did you not hear what I said? said Camier. Life. (Mercier, 53)

Although the Belacqua bliss that is referred to in the previous novels is not directly named by Mercier or Camier, it is still implied in the novel as the opposite of life, which is nothing but trivial things one has in his pockets. However, unlike Belacqua and Murphy, these characters are far from even a momentary Belacqua bliss. Despite the fact that they are more isolated from the physical world, they are also one step further in existential confusion, frustration, disorientation and the sense of hopelessness. They are not only incapable of naming what they aspire after, but they also have no sense of direction, which leaves them drifting in a perpetual purgatory.

There is a visible disintegration in these characters as well, both physical and mental. Much like their descendants, Vladimir and Estragon, Mercier and Camier suffer from physical disorders, such as cysts and limping legs; and while their bodies gradually decay through the journey, their minds are no better. They constantly try to remember what they did or said earlier that day and do not know what to do or where to go next. At some point, they cannot even find the right words to express themselves:

So they raised their glasses and drank, both saying, at the same instant or almost, Here's to you. Camier added, And to the success of our -. But this was a toast he could not complete. Help me, he said.

I can think of no word, said Mercier, nor any set of words, to express what we imagine we are trying to do. (Beckett, Mercier, 68)

As a result, Mercier and Camier strive to continue their journey with "the body in bits, the mind flayed alive" (Beckett, Mercier, 89). Their journey is a purgatorial one towards the now blurry Belacquan state, but it is a journey that is destined to fail, through which they endure physical and mental torments much like the souls in Dante's Purgatory, yet without the promise of a Belacquan Paradise, only with "the horror of existence" (Beckett, Mercier, 16). As Boulter asserts, "[t]he teleological purposefulness of Dante's [Comedy] highlights the essentially aleatory world of Mercier and Camier" (76). While the souls in Purgatory achieve Divine Wisdom and eternal salvation as a result of their suffering, what Mercier and Camier get is a perpetual Purgatory always with the same pubs in the same city, the same bogs in the same country, and the same feeling of not belonging. Correspondingly, Levy argues that "[m]ost of the novel... relives the Purgatorio, because it is here that we can best gauge the utter futility of their striving... Mercier and Camier can make no progress; they pass no fewer than four times through the same purgation for the same sin... Life itself is Purgatory for Mercier and Camier, who do again and again what they have already done, what they can never do for good" (119-122). During their endless journey through the same bogs, same streets, and same countryside, it is stated that "[h]ere would be the place to make an end. After all it is the end. But there is still day, day after day, afterlife all life long, the dust of that is dead and buried rising, eddying, settling, burying again" (Beckett, Mercier, 86). Commenting on this cyclical nature of the characters' journey, Acheson argues that "[u]nfortunately for Mercier and Camier both, 'thirsting in the dark'yearning, in other words, for the answers to unanswerable metaphysical questions - is an unalterable feature of the human condition. Though the 'essential salvation' the two of them appear to be seeking may well be a wish to be saved from the need to seek, that wish will always be denied them" (181). 
This assurance that their search will continue forever, perhaps even in the afterlife, indicates that Mercier and Camier will never reach that paradise-like Belacquan state. And since they are not even granted with death, which at least puts an end to the misery of Belacqua and Murphy; Mercier and Camier, as the Belacquas of the transitional period in Beckett's oeuvre, are doomed to this state of waiting, expecting, and wandering, which constitutes their purgatorial suffering.

\section{Echoes and Crawling Bodies: Unnamable and Pim}

Beckett's fiction in the fifties, sixties and afterwards is predominantly distinguished by a particular type of character who has lost his physical functions almost completely and exists merely as an echo of his past selves. Having achieved freedom from the burden of the body, however, these Belacquas are disillusioned with what they eventually have found. Coe summarises the condition of the later Beckettian everyman as follows: "Godot has come, and nothing essential has been changed" (83). Indeed, instead of enjoying the limitless pleasure of the anesthetised mind in the medieval Belacqua's Ante-purgatory, they find themselves in what can be considered as a different version of Dante's Inferno, where they are completely overwhelmed by mental anguish, having no sense of purpose, direction, or hope. In this hellish plight, they continue to suffer from their delusional minds, yet, they are obliged to keep talking in order to resume what is left from their fragmented existence. The loss of bodily function, which all Beckettian people seem to aspire, turns out to be not a bliss, but a state of constant decay and torment.

Unnamable, in the namesake novel (the Unnamable, 1953) belongs to this category of the later derelicts who more or less have lost their physical ability to move or function at all and have no connection whatsoever with the outer reality. With respect to the Trilogy, McDonald argues that "[s]uccessively, the stories within the whole move further and further away from a recognisable physical world, as the characters become first more debilitated and then, in The Unnamable, no longer recognisably human" (87-88). Indeed, Unnamable is merely a bodiless voice, and the whole novel is the interior monologue of this ceaselessly talking narrator who strives to name himself and complains about his condition. During his constant attempts to make sense of his existence, he tries to identify himself with the words he utters as follows: "I'm all these words, all these strangers, this dust of words, with no ground for setting... I'm something quite different, a quite different thing, a wordless thing in an empty place" (Beckett, Three, 379). Unlike Mercier and Camier, who are troubled by their mental confusion, yet occupy a space in the physical world, Unnamable is plunged into a condition where his utterances are nothing but delirium. Commenting on this hellish predicament, Pattie asserts that "[Unnamable] is trapped inside a narrative over which it has only the most tenuous control: and, what is more, Beckett's other characters are trapped with it, in a setting which seems to evoke Dante's Purgatory" (70). Further to Pattie's argument, the plight of Unnamable is of a crueller aspect than that of Purgatory, which can be described as a hellish Purgatory. In this merger of Inferno and Purgatory, Unnamable recalls or hallucinates his past selves, Malone and Molloy, who all share the same faith; the failure of the search. However, the fact that his predecessors have failed in their quest for the Belacqua bliss does not prevent Unnamable from pursuing the same objective. Despite his bodiless existence, delusional mind, and fragmented narration, Unnamable is aware of his impasse, which is to search for the Belacqua bliss that is forever denied: "how I manage, without feeling an ear on me, or a head, or a body, or a soul, how I manage, to do what, how I manage, it's not clear, dear dear, you say it's not clear, something is wanting to make it clear, I'll seek, what is wanting, to make everything clear, I'm always seeking something, it's tiring in the end, and it's only the beginning" (Beckett, Three, 380). Accordingly, what is left for Unnamable is merely talking about this futile quest, rather than actually doing something about it unlike the earthlier Belacquas. Fowlie asserts that "[f]or the early characters of Beckett no voyage in supernatural sense is possible, and for the later characters in his writings - after Molloy - there will be no moving ahead, no voyage possible in even the natural sense" (131). Indeed, while the earlier derelicts are at least physically able to attempt to release themselves from the burden of the physical world, later heroes, like Unnamable, are denied not only mental lethargy, but also physical ability to pursue that state. 
As in the Unnamable, this last stage of the predicament of Beckett's people can also be observed in Beckett's How It Is. The novel's narrator, Pim, is an old deformed body that crawls through the mud throughout the novel, constantly talking as if in hysteria, and remembering his past selves, namely the earlier Belacquas, such as Murphy, Watt, Mercier, Molloy and so forth. He constantly assumes a similar posture to that of Dante's Belacqua, and pinpoints that similarity as follows: "clasped to my belly the knees drawn up the back bent in a hoop the tiny head near the knees curled round the sack Belacqua fallen over on his side tired of waiting" (Beckett, How It Is, 18). Pim's crawling is hardly a movement, however, he is still striving to achieve that Belacqua bliss, which his predecessors enthusiastically pursued, without knowing that he is trapped in a world where even a twisted sense of salvation is denied for mankind. As Kalt also points out, "[in] How It Is the dictates of divine order in a balanced cosmos have become senseless screamings in a chaotic void" (31). Recalling his past selves and past attempts to reach Belacquan Paradise, like Unnamable, Pim acknowledges the failure of his strife: "my life above what I did in my life above a little of everything tried everything then gave up no worse always a hole a ruin always a crust never any good at anything not made for that farrago too complicated crawl about in corners and sleep all I wanted I got it nothing left but to heaven" (Beckett, How It Is, 67). While the promise of a Belacquan paradise is proved to be a disillusionment, the suffering and torments still continue with the narrator dragging his dysfunctional body through the mud and his flesh being tortured by another version of himself. For Kenner, How It $I s$ is "Beckett's Inferno, told from the inside, not like Dante's from the standpoint of a privileged tourist, and in its starkness, uncertainty, and paradoxical intelligibility a very twentieth-century hell" (146). In Pim's case, the earlier Belacquas' search for a paradise-like Ante-purgatory becomes Inferno itself, where the Beckettian man is forsaken, disillusioned with the promised land, deprived of the privilege of death, confused about the aim of his crawling, doomed to suffer eternally, and yet still feels obliged to move and talk and express himself, even though there is nothing to express except his own delusions.

\section{Conclusion}

Beckett's fictional universe is characterised by a gradual decay and inevitable failure for the individual. Considering the trajectory of Beckett's fiction, Fletcher points to "the steady decomposition of the Beckettian hero from the Belacqua of Dream to the man in the mud of How It Is, a breakdown that reflects, and is reflected in, the corruption of the fictional medium" ("In Search of Beckett," 33). Indeed, what begins as an idealistic quest towards the freedom of the mind from the burden of the body turns into a perpetual torment, a journey that has no destination, and a waiting that has no end. As the condition of these Belacquas deteriorates, the purpose of waiting and suffering becomes blurrier and more elusive for them. As Fowlie also argues, "Purgatory is indeed the home of Beckett's characters ... [who] wait without knowing what they wait for" ("Dante and Beckett" 141). This is the summary of the plight of Beckett's people, particularly the later outcasts, deformed bodies, and bodiless echoes. Beckett denies granting his people the blissful nothingness or a quick death, since that is not how life works according to his pessimistic worldview. Despite the fundamental influence of Dante's Belacqua on Beckettian modern everyman, this is where Beckett's world parts with and overturns the blissful negligence and numbness which Dante's Belacqua is allowed to relish and Beckett's Belacquas attempt to acquire. While Beckett turns Belacqua, whom Dante presents as a sinful soul bearing the punishment determined for him with consent, into an incentive model for his characters, he also makes it impossible for them to achieve what seems to be a blissful state. When asked about his thoughts on the notion of hope, Beckett replies by quoting from Dante's Comedy: "I would have written over the gates of Heaven what is said to be written over Hell - abandon all hope ye who enter here... That's what I think of hope" (qtd. in Cronin, 568). Indeed, the faith of his fictional everyman is shaped according to this perspective. In Beckett's vision, not only a Dantean sense of Paradise, but also a Belacquan numbness cannot ease the pain of being alive. His Belacquas are not as lucky as their medieval ancestor, who enjoys his lethargic rest knowing that he will eventually be saved. In his letter to his friend, Kay Boyle, Beckett admits that for him, Belacqua "is no more than a kind of fetish [and with How It Is] I hope that's the end of him" (qtd. in Caselli, Beckett's Dantes, 151). Indeed, Beckettian man is not allowed to go further than Pim's impasse in the mud in How It Is. However, since it is a lifelong obsession, How It Is does not bring the end of Belacqua, and he appears in Beckett's later short prose, such as the Lost Ones (1970) and the Company (1979). At this point, the 
reason for Belacqua's persistent presence as Beckettian everyman can be explained by referring to his very presence in Comedy. Dante's Belacqua, first and foremost, is a soul who is told to wait for a lifetime in order to be saved, and he is made sure that this waiting will result in his eventual salvation. In Beckett's universe, he is transformed into the modern individual who has to wait, but with no hope of being saved, and who is not quite sure if he can even be saved from the burden of being alive. As Beckett's attitude towards life grows more cynical and pessimistic, the condition of his modern Belacqua declines while the futile waiting remains.

\section{WORKS CITED}

Acheson, James. "Samuel Beckett's Early Fiction and Drama: A Study of Artistic Theory and Practice.” Diss. University of Canterbury, 1988. ProQuest. Web. 3 Sep 2020.

Alighieri, Dante. The Divine Comedy. Trans. Laurence Binyon. Ed. Paolo Milano. NY: Viking, 1956.

Beckett, Samuel. Dream of Fair to Middling Women. NY: Arcade, 2012.

---. Mercier and Camier. London: Faber and Faber, 2010.

---. Murphy. London: Pan Books, 1973.

---. How It Is. London: Faber and Faber, 2009.

---. Three Novels: Molloy, Malone Dies, The Unnamable. NY: Grove, 2009.

Bergin, Thomas Goddard. Dante's Divine Comedy. Englewood Cliffs, NJ: PrenticeHall, 1971.

Boulter, Jonathan Stuart. "“The Impossible Voice: Hermeneutics and Narrative in Samuel Beckett's Novels." Diss. The University of Western Ontario, 1996. ProQuest. Web. 5 Sep. 2020.

Brandeis, Irma. The ladder of Vision: A Study of Dante's Comedy. London: Chatto \& Windus, 1960.

Caselli, Daniela. Beckett's Dantes: Intertextuality in the Fiction and Criticism. Manchester: Manchester UP, 2005.

Coe, Richard N. Beckett. Edinburgh: Oliver and Boyd, 1968.

Cohn, Ruby. Back to Beckett. NJ: Princeton UP, 1973.

Cronin, Anthony. Samuel Beckett: The Last Modernist. NY: De Capro, 1999.

Eliot, T.S. "Dante." The Complete Prose of T. S. Eliot: The Critical Edition: Literature, Politics, Belief, 1927-1929. Eds. T. S. Eliot \& F. Dickey \& J. Formichelli \& R. Schuchard. Baltimore: The Johns Hopkins University Press, 2015. Project MUSE. Web. 3 Sep. 2020.

Federman, Raymond. Journey to Chaos: Samuel Beckett's Early Fiction. Berkeley: U of California P, 1965.

Fletcher, John. Samuel Beckett's Art. London: Chatto \& Windus, 1967.

---. The Novels of Samuel Beckett. London: Chatto, 1964.

---. "In Search of Beckett.” Beckett at 60. London: Calder and Boyars, 1967.

Fowlie, Wallace. "Dante and Beckett." Dante Among the Moderns. Ed. Stuart Y. McDougal. Chapel Hill and London: U of North Carolina P, 1985. 
Kalt, Ursula. "Birth, Death and Salvation of Beckettian Man." Diss. Florida Atlantic University, 1982. ProQuest. Web. 5 Sep. 2020.

Kenner, Hugh. A Reader's Guide to Samuel Beckett. NY: Farrar, Straus and Giroux, 1973.

Levy, Eric P. “"Mercier and Camier': Narration, Dante, and the Couple." On Beckett: Essays and Criticism. Ed. S. E. Gontarski. NY: Grove, 1986.

McDonald, Ronan. "Samuel Beckett's Postmodern Fictions." The Columbia History of the British Novel. Ed. John Richetti. NY: Columbia UP, 1994.

O’Neill, Kevin Charles. "The Voyage from Dante to Beckett.” Diss. University of California, 1985. ProQuest. Web. 6 Sep. 2020.

Pattie, David. Samuel Beckett. Oxon: Routledge, 2000. googlebooks. Web. 6 Sep. 2020.

Sperandio, Renata. "Dantean Reverberations: Four Readers of Dante in the Twentieth Century. A study on the Dantes of Primo Levi, Edoardo Sanguineti, Samuel Beckett and Seamus Heaney." Diss. The University of Birmingham, 2009. ProQuest. Web. 6 Sep. 2020 .

Strauss, Walter A. "Dante's Belacqua and Beckett's Tramps." Comparative Literature, Vol. 11, No.3 (1959), 250-261. JSTOR. Web. 6 Sep. 2020.

Thomas, Dylan. Rev. of Murphy, by Samuel Beckett. New English Weekly. 17 Mar. 1938: 5051. Web. 6 Sep. 2020.

Wallace, David. "Dante in English." The Cambridge Companion to Dante. Ed. Rachel Jacoff. $2^{\text {nd }}$ Ed. Cambridge: Cambridge UP, 2013.

Webb, Eugene. Samuel Beckett: A Study of His Novels. Seattle: University of Washington P, 2014. 